\title{
CURRENT CONFESSIONAL STRUCTURE OF THE POPULATION OF BULGARIA
}

\author{
DOI: http://dx.doi.org/10.18509/GBP.2020.34 \\ UDC: 314.117:316.347(497.2)"1992/2011"
}

\section{Toni Traykov}

Sofia University “St. Kliment Ohridski, Bulgaria

\begin{abstract}
The formation of the current confessional structure of the population of Bulgaria has been a long process influenced by the peculiarities of the historical development of the country. The adoption of Christianity, in 865, as an official religion of the First Bulgarian State contributed to the amalgamation of the ethnic groups constituting parts of the Bulgarian nationality formed in the $\mathrm{X}$ century. In this way, the new religion displaced the old pagan beliefs and helped build a common national consciousness among the Bulgarians. As a result, they became part of the unified - until the middle of the XI century - Christian world. Following the Great Schism of 1054, Bulgaria and the Bulgarians remained in the sphere of Orthodoxy. The settlement of Christian Catholics and Jews in certain parts of Bulgaria was responsible for some diversity in the confessional structure of the population of the country during the Middle Ages. The fall of Bulgaria under Ottoman rule (1396) resulted in the emergence of a new confessional community, namely, the Muslim one. Its establishment was reinforced by the deliberate policy on the part of the Sultan authorities towards forcible Islamization of a part of the Bulgarian population. Despite its loss of statehood for five centuries, the Bulgarian people managed to preserve their ethnic consciousness and affiliation with Orthodoxy. The first censuses following the Liberation of Bulgaria (1878) showed that the main part of the population had retained its Orthodox orientation. The censuses of 1955, 1965, 1975 and 1985 did not collect information on the population's religion. The change in the census program was a result of the influence of the then dominant communist ideology and propaganda against religion and religious beliefs. As a result of the democratic changes in 1989, the question on the confession of the peopulation was included again in the Census Monitoring Programs in 1992, 2001 and 2011. As a new development in the 2001 census can be considered the voluntary nature of the answers to the questions related to ethnicity, mother tongue and religion of the population. The results of the latest population censuses in Bulgaria have shown that Eastern Orthodox Christianity has retained its position as the dominant religion in Bulgaria. Orthodoxy still prevails in 26 of all 28 administrative districts of the country. The confessional communities of Muslims, Christian Catholics and Protestants, Jews and others are much smaller in number. They were formed during different historical periods and are now represented in certain parts of Bulgaria.
\end{abstract}

Keywords: population of Bulgaria, religions, confessional structure

\section{INTRODUCTION}

People's affiliation with a particular confessional community affects their way of life, behavior and communication. The importance of confessional communities is also linked to the ethnic self-determination of peoples. Religion is therefore identified as an important ethno-demographic feature. Differences in the ethnic affiliation of peoples are an 
important factor in international relations in different parts of the world [5]. The formation of the contemporary confessional structure of the population in Bulgaria is a long process, influenced by the peculiarities of its historical development. Adoption of Christianity in 865 as an official religion in the First Bulgarian State, it is an important factor for the unification of the ethnic groups that were part of the Bulgarian nationality formed in the $\mathrm{X}$ century. In this way, the new religion displaces the old pagan beliefs of the ProtoBulgarians, Slavs and Thracians and helps to build a common national consciousness in the Bulgarians. Thus, they became part of the Christian world, united by the middle of the XI century. After the Great Schism in 1054. Bulgaria and the Bulgarians remain in the sphere of Orthodoxy. The proclamation of the Bulgarian Patriarchate by Tsar Simeon I in 917 contributed to the establishment of the Orthodox Church in Bulgaria. It was recognized by the Patriarch of Constantinople in 927. and so ranks among the five most ancient patriarchs of the Eastern Christian world. The confessional orientation remained unchanged, despite the union between Rome and the Bulgarian ruler Kaloyan in 1204. The Bulgarian Church temporarily acknowledges the Pope's supremacy, but retains its Eastern Orthodox liturgical practice. In 1235. The Bulgarian ruler Tsar Ivan Alexander II put an end to the union and completely restored the Bulgarian church to Orthodoxy. The settlement of Christian Catholics and Jews in certain parts of its territory is introduced by the diversity of the confessional structure of the population in Bulgaria during the Middle Ages. The fall of Bulgaria under Ottoman rule (1396) determined the formation of a new confessional community - the Muslim one. Its purpose in certain parts of the Bulgarian lands is to contribute to its consolidation of the Muslim population and the forced Islamization of a part of the Orthodox Bulgarian population. Such actions are carried out mainly in the inaccessible mountain areas, as well as in the vicinity of strategic military roads and mountain passes. Despite the loss of its statehood for five centuries, the Bulgarian people managed to preserve their ethnic self-consciousness and their affiliation with Orthodoxy. The Bulgarian Orthodox Church contributes to this, which, although in the "shadow of Islam", becomes the unifier of ideas for national recognition and revival of Bulgarian statehood.

\section{DATA \& METHODS}

After the Liberation (1878), as a result of the displacement of a significant number of Turks, Tatars and Circassians in Bulgaria, the majority of the Bulgarian Orthodox population increased. The first official census of the population shows that the main religion in the country is Orthodoxy, which is professed by the majority of the population. Within the boundaries of the Principality of Bulgaria, the pre-eminent population is increasing by 2,424 thousand. of the 1887 census. to the 3019,000 census in 1900 . Due to expulsions abroad, Muslims reduced by 676 thousand during the same period. at $\$$ 643,000 Third in number at that time were the professors of Judaism, who increased their numbers by 24,000 . in 1887 . at $\$ 34,000$ in 1900 . The remaining even smaller confessional communities (Catholics, Protestants, Armenian-Gregorians, etc.) form only about $1 \%$ of the total population. The quantitative changes related to the number of professors of different denominations in Bulgaria are accompanied by changes in their territorial distribution. In the plains and larger cities at the same time as the restoration of the Bulgarian appearance, the share of Eastern Orthodox at the expense of Muslims is increasing. Despite the mass exodus, the compact nature of Muslims in some parts of the Rhodope Mountains, northeastern Bulgaria and other smaller territories remains. The spread of the Mohammedans and some of the Roma professing Islam also contributes to 
this. A characteristic feature of the distribution of Judaists and Armenian-Gregorians is their concentration in the larger cities, where their prayer houses and temples are located. Censuses in the first half of the twentieth century introduced some changes in population reporting methodology. As a feature of the 1934 census. the fact that the question of religion is determined in terms of the religious practices practiced: Eastern Orthodox, Catholic, Muslim, etc. can be pointed out. In cases where a person is a follower of a particular church or religious sect, his or her name must be given: Uniate, Adventist, Old Believer, etc. The 1946 census. retains the program of the previous census of 1934, but when processing the results, accepts persons who have indicated a Catholic or Protestant religion to belong to the category of "other or not shown population". As a result, the number of persons in this category has increased several times.

The 1956, 1965, 1975 and 1985 censuses. the sign "religion" was excluded from the surveillance program in accordance with the prevailing communist ideology. Under her influence, militant atheism was imposed in the country and the perception that the Bulgarian people was atheistic in nature. The 1992, 2001 and 2011 censuses. issues of religion, ethnicity and mother tongue are again included in surveillance programs. The new attitude towards religion and religion is the result of the democratic changes in Bulgaria after 1989. The Constitution, adopted in 1991, states that the state is a guarantor of civil rights and must "provide the necessary conditions for the free and unhindered exercise of the personal right of religion of every Bulgarian citizen." As a new moment of the 2001 census. the voluntary nature of the answers to the questions concerning belonging to an ethnic group, mother tongue and religion may be indicated, unlike all previous censuses (Art. 5, Para. 3 of the 2001 Census Act) [ 2].

Data from the last census in 2011. show that Eastern Orthodox Christianity still maintains its position as a defining religion in Bulgaria. To him in 2011.4374 thousand or $76.0 \%$ of the persons who voluntarily indicated their religion. The decrease compared to 2001. $(82.6 \%)$ is due to negative natural growth, emigration and a significant proportion of unanswered questions, especially among younger age groups. The censuses carried out in the country show some fluctuations in the relative shares of Eastern Orthodox [4]. They varied from $76.9 \%$ in 1887 . to $85.7 \%$ in 1992 . and again to $76.0 \%$ in 2011 . At the last census in 2011. 272.3 thousand people (4.7\%) indicated that they had no religion and 409.9 thousand. $(7.1 \%)$ did not self-identify.l

In terms of the territorial distribution of the Eastern Orthodox confessional community, it has the highest relative share in Western and Central Bulgaria (Figure 1) with the exception of their southern parts (significant parts of the Rhodope Mountains and the Mena River valley). In 2011. to Eastern Orthodox Christianity are more than $85 \%$ of the self-identified in the districts of Kyustendil (87.5\%), Sofia-region (87.3\%), Sofia-capital $(86.2 \%)$, and Pernik (85.2\%). Higher than the national average $(76.0 \%)$ is the share of self-identified as Eastern Orthodox in the districts of Vidin (84.5\%), Gabrovo (84.0\%), Vratsa (81.8\%), Veliko Tarnovo (79, 5\%), Stara Zagora (79.5\%), Varna (78.8\%), Pleven (78.5\%), Montana (77.5\%) and Lovech (76.7\%). In all these areas there is a high degree of overlap between ethnicity and religion. Eastern Orthodox Christianity as a whole also applies to the Bulgarian ethnic community. The decisive influence of Eastern Orthodoxy is also expressed in terms of municipalities. Of the 265 municipalities in Bulgaria, about half have about and over $80 \%$ relative share of the self-determined to Eastern Orthodoxy. The municipalities of Chavdar, Georgi Damyanovo, Novo selo, Belovo, Nevestino, Sapareva banya, Boynitsa, Boboshevo, Treklyano and others have the highest share of Eastern Orthodox (over 90\%). 
The second, but much smaller, confessional community in Bulgaria is the Muslim one. The relative share of professing Islam in our country is highest in the census in 1887. $21.4 \%$, the lowest since the last census in 2011. - 10.0\%. In absolute numbers in 2011. \$ 546,000 identified themselves as Sunni Muslims, \$27.4,000 as Shi'a Muslims, and \$ 3.7,000. have indicated only the Muslim religion. The fluctuations in the number of Muslims in the country are the result of emigration waves to neighboring Turkey, which largely offset their natural growth.

The geographical spread of the Muslim confessional community in Bulgaria depends on the spread of the Turkish ethnic group and, to a lesser extent, on the spread of the Mohammedan Bulgarians and that part of the Roma who profess Islam. With the highest proportion of Muslims in 2011. the districts are Kardzhali (70.1\%), Razgrad (50.6\%), Smolyan (39.8\%), Targovishte (38.1\%) and Shumen (33.9\%) (Figure 2). A significant number of Muslims also live in the districts of Plovdiv, Burgas and Blagoevgrad, but they are below $20 \%$ of the total population.

Territorial peculiarities also exist in the spread of Shi'a Muslims, known as Alians, Alevites, and Kozlibashi. The Alians live mainly in northeastern Bulgaria and more specifically in the districts of Silistra, Razgrad and Dobrich. Altogether, the three districts account for $33.7 \%$ of the self-identified in the Shiite area of Islam. In these areas are also the municipalities with the highest proportion of Shi'a Muslims: Kainardzha, Dulovo, Kubrat and others.

In third place by number in 2011 ranks the confessional community of Protestants. At the census that year, 64.4 thousand $(1.1 \%)$ self-identified. At the previous census (2001) Protestants occupied the fourth position after the community of Catholics. In practice, for the period between the last two censuses, Protestants are the only confessional community to increase the number of its members. Protestantism is not uniform in its orientation. There are 19 Protestant communities and groups with over 1200 local divisions and groups in different settlements in Bulgaria. The increased influence of Protestantism as a whole is the result of the active missionary activity of the various Protestant churches in Bulgaria after 1989, including among the Roma population. The territorial spread of the Protestant community in recent decades has been associated with large cities and municipalities with a compact Roma population. In 2011. Lom, Sliven, Ihtiman, Kotel, Maglizh, Varbitsa and others are designated as such.

The fourth largest religious community in Bulgaria is the Catholics. In 2011. it includes 48.9 thousand, representing $0.8 \%$ of the total number of persons who self-identified by religion. The formation of the Catholic confessional community in Bulgaria began in the Middle Ages with the settlement of Saxon miners in the area of Chiprovtsi. The increase in the number of Catholics since the Liberation is associated with the active work of Catholic missions, including the construction of churches, schools and orphanages. The increase in the number of Catholics in Bulgaria after the 1992 census. This is due to the fact that many children in mixed marriages between Catholics and Orthodox are switching to the Catholic religion. In terms of territoriality, Catholics in Bulgaria are associated with certain parts of the country. Census data for 2011 show that $57.1 \%$ of the Catholics in Bulgaria live in the districts of Plovdiv, Pleven and Veliko Turnovo, and only in the district of Plovdiv - 39.8\%. The municipalities of Rakovski, Belene, Kaloyanovo, Levski, Svishtov, Hisarya and Byala Slatina have the highest number of Catholics in Bulgaria. Among them is the municipality of Rakovski, where Catholics are over half the population. In his survey of confessional communities in Bulgaria at the end of the 20th century, Ch. Mladenov (1997) noted the differences in the territorial 
distribution of Catholics and Protestants in the two main types of settlements. According to him, the relative proportions of Catholics in urban and rural populations are the same $(0.6 \%$ each), while Protestants dominate the urban population $(0.3 \%$ in cities versus $0.1 \%$ in villages) [3].

At the 2011 census. The category of other denominations in our country include some smaller confessional communities, including 11.4 thousand. or $0.2 \%$ of those who answered the religion question. Communities with Armenian-Gregorian and Jewish denominations are traditional for Bulgaria. Settlements of the followers of Judaism (Jews) in the Balkans began in antiquity and the Middle Ages. Armenians settled in Bulgaria in the early 20th century, fleeing persecution in the Ottoman Empire. As a result of the expulsions of Armenians and Jews after World War II, their numbers have repeatedly decreased. In 2011. only 706 people have identified themselves as professors of Judaism. The followers of the Armenian-Gregorian religion are 1725 people. As in the past, the centers of the two religious communities are the major cities in the country, such as Sofia, Plovdiv, Varna, Rousse, Burgas, Shoumen and others.

\section{DISSCUSION \& CONCLUSION}

The few confessional communities in Bulgaria include the followers of some nontraditional denominations such as the Danes (White Brotherhood), Buddhists, Bihans, and others. In our communities, a number of religious movements and sects, such as Jehovah's Witnesses, War of Christ, International Society for Krishna Consciousness, and others, are also represented in small communities. According to B. Assenov (1998), sectarian groups are spread on a Christian (mainly Protestant), Muslim, Hindu, and HinduChristian basis [1].

The preservation of the traditional religions and related confessional communities for our country for centuries is indisputable proof of the religious and ethnic tolerance of the Bulgarian people. A new moment in the religious life in Bulgaria is the entry of some non-traditional religious movements and sects, which have a limited number of followers among the population.

\section{REFERENCES}

[1] Assenov, B. Religions and Sects in Bulgaria. S., 1998.

[2] Balev, Iv. Demographic characteristics of Bulgaria. Cc. Statistics, Issue 6, S., 2001.

[3] Mladenov, Ch. Religious Composition of the Population in Bulgaria. Geography of Bulgaria. Edition of BAS. S., 1997.

[4] Naydenov Kl. Modern migration processes and attitudes of the population in the Republic of Bulgaria - factors and trends, International Scientific Conference GEOBALCANICA 2019, http://dx.doi.org/10.18509/GBP.2019.50

[5] Naydenov Kl. Human resources development as a factor for regional development, International Multidisciplinary Scientific GeoConference: SGEM, 2019, doi: $10.5593 /$ sgem $2019 / 5.4 /$ S23.063 